\title{
NATO and the Role of Societal Resilience and Willingness to Defend Own Country
}

Mārtiṇš Vargulis (ORCID: 0000-0002-3969-0331), Rīga Stradiņš University and Latvian Institute of International Affairs https://doi.org/10.25143/willingness_to_defend_2021_ISBN_9789934563997_18-28

Global connectivity, technological development, information, and psychological operations as well as other evolving elements present new security challenges for NATO, especially in relation to the resilience of society. Alongside strengthening collective defence, building resilience through civil preparedness and innovation will be a game-changer for the ability to withstand any form of aggression in future. In the long-term perspective, it will require a swift adaptation to new innovations and technology, as well as the readiness and willingness of society to take a part in defending own country. State and non-state actors will need to be engaged to maintain and enhance the security of Allies. The resilience of the society is becoming one of the dominating centres of gravity within the context of modern warfare. It is a precondition of credible deterrence and defence posture - a complementing aspect to the collective defence.

Russia's aggression in Ukraine stimulated discussion of societal elements in the overall deterrence and defence planning among Allies. Although the concept within NATO is still under development, several conclusions can already be drawn about how the Alliance perceives the resilience and what impact it may have on the overall NATO's adaptation process, including within the discussion surrounding the formulation of the new Strategic Concept. Therefore, the purpose of this chapter is to analyse what collective defence measures have been adopted in recent years and how they relate to the overall resilience of the Alliance and willingness of the society to defend own country - and those of Allies. 


\section{Renaissance and dynamics of the resilience within NATO}

Considering the lessons learned from Russia's aggression in Ukraine since 2014, the issue of the resilience of Alliance became an indispensable element. From the Wales Summit in 2014 to the Brussels Summit in 2021, the concept of resilience has undergone a transformation. In the declaration adopted by the Heads of State and Government in 2014, the concept of resilience was described only through the prism of the cyber dimension. The Enhanced Cyber Defence Policy was endorsed. Overall, it contributed to the fulfilment of the Alliance's core tasks. It recalled that the "fundamental cyber defence responsibility of NATO is to defend its own networks, and that assistance to Allies should be addressed in accordance with the spirit of solidarity, emphasizing the responsibility of Allies to develop the relevant capabilities for the protection of national networks". ${ }^{1}$

At the Warsaw Summit in 2016, resilience was further emphasized in the context of the overall agenda. It was linked not only to the cyber dimension, but to the wider debate on societal resilience. In addition to reinforcing collective defence and enhancing capabilities, strengthening resilience was described as an incremental pillar of adaptation process of the Alliance. As stated in the declaration, "[Heads of State and Government] made a commitment to continue to enhance resilience and to maintain and further develop individual and collective capacity to resist any form of armed attack". 2

The policy adapted at the Warsaw Summit emphasized that resilience must be seen first and foremost through the prism of national responsibilityas an expression of Article 3. Heads of State and Government in 2016 reinforced the Resilience Guidelines that were adopted by the ministers of defence in 2016 prior to the Summit. Resilience Guidelines set by NATO focused "on continuity of government and essential services, security of critical civilian infrastructure, and support to military forces with civilian means"3. By adopting a new sustainability policy, the Allies acknowledged that the security issue was complex and comprehensive, requiring a coordinated and unconventional solutions. It also pointed to the need for a long-term development and adaptation. To face the challenges of the new security environment, Allies need to develop critical civilian capabilities, alongside and in support of military capabilities. It also requires intensified 
and integrated cooperation between entire government and private sector. Thus, strengthening whole of government approach. The policy required resilience to be seen in the context of NATO's defence capabilities and operational planning. This is a new precondition for strengthening overall deterrence and defence posture.

Unlike previous summits, the policy in Brussels Summit in 2021 envisaged an increasing role for NATO in developing and advancing the requirements of resilience. Although the perception of Heads of State and Government that resilience is first and foremost a national responsibility hasn't significantly transformed, a number of strengthening elements in 2021 have been introduced. In the light of the collective commitments set out in Article 3 of the North Atlantic Treaty, a number of integrated measures have been adopted to strengthen the overall resilience of the Alliance. It is important that the principles of resilience are linked to any type of contingency - peace, crisis, as well as to conflict. In the Brussels Summit it was agreed that "Allies will develop a proposal to establish, assess, review, and monitor resilience objectives to guide nationally developed resilience goals and implementation plans [and] that it will be up to each individual Ally to determine how to establish and meet national resilience goals and implementation plans, allowing them to do so in a manner that is compatible with respective national competences, structures, processes and obligations"4. Thus, the role of the Alliance in the overall supervision of the resilience increased.

In order to fulfil the Alliance's core tasks and strengthen the credibility of the Alliance resilience is essential and of utmost importance. Therefore, at the Brussels Summit leaders went further and agreed that resilience isn't just a national responsibility, but also a collective commitment. The importance of the resilience in the overall discussion within NATO was shown by the establishment of the Euro-Atlantic Centre for Resilience that is located in Romania.

To ensure a coherent approach, the Alliance's role is expected to increase in the future. Today, each country still has a different understanding of what measures need to be taken and what effect they have on the overall sustainability of the Alliance. The creation of guidelines and rules is a step in the right direction in the context of the overall adaptation process of the Alliance. 


\section{Strengthening (improving) the concept of resilience}

According to Sun Tzu, supremacy derives from a conquest without fighting. In the book "Art of War", he stressed the excellence of victorious leaders who had won before a battle even started, opposed to the failures of those who first went to war, attempting to win thereafter. Thus, power derives from the skill to break the enemy's resilience without firing a single shot. The same importance of the resilience could be perceived through the prism of deterrence. As very clearly described by the Ministry of Defence of the United Kingdom “... deterrence is a general reputation, generated over time by a posture (and visible actions) that portrays an image of credibility and resilience regarding any hostile intent. This reputation is built by how adversaries interpret that posture. It is essential to understand that posture is not the same as reputation" ${ }^{5}$. In practice, deterrence by denial consists of resilience and entanglement. It is vital to understand the value of resilience, indisputably the less glamorous part of deterrence and one that has long been treated as an afterthought ${ }^{6}$. Despite this neglected position, deterrence by resilience can significantly change the attacker's cost-benefit calculation. Successful deterrence is based on resilience.

Recognising the complexity and importance of the issue of the resilience, the Alliance has gone further and set out additional steps to take a wholeof-government approach to enhancing the resilience of societies. Whole-ofgovernment approach involving most of the government institutions into defence planning is of utmost importance to ensure resilience in various dimensions and fields. In this context, the Alliance has adopted "seven NATO Baseline Requirements for national resilience, through enhanced civil-military cooperation and civil preparedness; closer engagement with populations, the private sector, and non-governmental actors; and the centres of expertise on resilience established by Allies"7. Especially, civil preparedness has been perceived as a central pillar of the whole-ofgovernment approach. It is a "game changer" for the overall Alliance's deterrence and defence posture. Enhancing civil preparedness will be crucial in ensuring the credibility of the posture. NATO's increased role and shared responsibility among Allies will be a important precondition to deliver it.

Among other critical infrastructure, supply chains, and communication information networks, including $5 \mathrm{G}$, are the most common elements found 
in the Alliance's debate on resilience. Given the growing activity of Russia and China, the ability to meet these challenges is becoming vital to the overall deterrence and defence posture of the Alliance. Launching the \#NATO2030 process, NATO Secretary General Jens Stoltenberg pointed out that "credible deterrence and defence are central, because "the best way to prevent a conflict, is to remove any room for doubt, any room for miscalculation about NATO's readiness, willingness to protect all Allies." ${ }^{8}$ He also underscored that resilience is key and "that resilience - be it infrastructure, telecommunications, $5 \mathrm{G}$ or healthcare, access to protective equipment - all of that matters for the civilian society, but it actually also matters for NATO as a military alliance and our military capabilities." ${ }^{9}$ This confirms the assumption that, whatever adaptation processes take place, the overall resilience of the Alliance is one of the key pillars of the future of the Alliance.

Brussels Summit in 2021 was affected not only by the adaptation processes that began at the Wales and Warsaw summits and the increasing notion of the importance of technologies, but also by the global pandemic and the Alliance's ability to meet such unprecedented challenges. This has added a new dimension to the resilience. The challenges posed by COVID-19 call for new measures. The compatibility of the civil, environmental, health, economic and political spheres with the military takes on an even more pronounced hue. Like other organizations, NATO was not prepared to face challenges at the beginning of the pandemic. Military exercises were abolished, decision-making was interrupted, and coordination between the Allies was undermined. Although the Alliance had the ability to find shortterm solutions more rapidly than other organizations, long-term resilience to such challenges needs to be strengthened. The need for military involvement and integration with the civilian sphere in today's hybrid warfare will only increase. Separating them would be an inappropriate approach, which would undermine the Alliance's resilience to external threats, which may be caused by both national ambitions and international disasters. Success will be based on NATO's ability to coordinate and supervise the integration of civil and military sectors.

Current challenges require NATO to continue to strengthen its resilience. Joint and coordinated action between the Allies will be an essential precondition for promoting common sustainability. At the same 
time, cooperation with partners and international organizations matters. First, it provides the best solutions for strengthening resilience. Second, it mutually strengthens and enhances overall security in the Euro-Atlantic area. In this context, the cooperation with the EU is vital. In a crisis and conflict situation, the EU's role in providing civilian support to military operations will be crucial in the context of the success of the joint operation. Strengthening the overall resilience of NATO and EU requires enhanced cooperation between both organizations in the form of joint civil-military exercises and common regulations, as well as information exchange.

\section{Shared threat perception and solidarity as preconditions of resilience}

Strength and power are elements that Russia respects. To have credible deterrence, the Alliance needs to strengthen and to demonstrate its ability to use might and power, if that is required. A demonstration of strength, which could be expressed both in large-scale exercises and deployment of permanent Allied forces, is the best signal to the aggressor that the defence of each country, and thus of the Alliance as a whole, is being seriously planned, tested and valued. Softening and reducing positions will be perceived as a point of weakness that Russia will utilize according to its own interests. Therefore, measures adapted since 2014, including in the Baltic region, is the (minimum) basis in the current security environment on which the Alliance's common deterrence and defence policy should be further strengthened.

Solidarity and the desire to protect the country are two other highly valued elements in the administration of Vladimir Putin. According to Russia's General Gerasimov's doctrine, influencing public sentiment in a way that provides a basis for military intervention is one of the main centres of gravity of the operation. Accordingly, the strength (or weakness) of states depends directly on society's willingness to protect its country as well as Allies, if that is required.

One of the essential elements of the resilience and solidarity is the common understanding of the level and classification of threats. As mentioned in 
the previous chapters, following Russia's aggression in Ukraine, several decisions were taken at the Wales Summit in 2014 and at the Warsaw Summit in 2016, which illustrated the change of consciousness and mindset among Allies. Both summits indicated that Allies have "come to" a common threat perception where Russia's aggression in Ukraine creates a long-term consequence for the transatlantic security. A common understanding of Russia's ambitions and its revisionist approach in the international arena was demonstrated. That was a turning point for the security of the Baltic states. Prior to Russia's aggression in Ukraine, several Central and Western European Allies were rather interested in normalizing relations with Russia, even in the form of civil-military cooperation. From the perspective of Baltic states, such an approach was considered as unfavourable and risky, based on the national threat assessment. Nevertheless, the Heads of State and Government in Wales and Warsaw were able to agree on far-reaching measures to strengthen the Alliance's collective defence and rapid response capabilities, as well as the re-enforcing of the central role of transatlantic relations in ensuring security, while maintaining a clear and common understanding of the threat and challenges the Alliance is facing.

Although there was emerging unity among the Allies at the 2014 and 2016 summits, in recent years, national interests and perceptions have come to the fore again. Russia's aggression in Ukraine and aggressive assertiveness expressed in many forms are no longer a unifying threat that bring all these actors together. In this regard, Baltic states have a completely different perception compared to other Allies - being very sceptical of Russian military activism in the Baltic Sea and other surrounding regions. Consequently, resilience in the context of NATO must be seen in the broader sense of solidarity and unity among Allies. Although resilience is primarily a national responsibility, it is the shared understanding among Allies that will determine the extent to which collective defence is corresponding with existing challenges. To ensure the willingness and readiness of society to be involved in defending itself and its Allies, a common threat perception communicated by the political and military leaders is vital. 


\section{Understanding the necessity and willingness to defend (not only) own country}

The willingness to protect Allies and engage in conflict (if that is the case) is an essential deterrent element. There are several ways in which the willingness to protect the Allies can be projected, demonstrated and analysed. One of the most striking forms of expression, which has contributed to the calculation on the aggressor's side, is the deployment of Allied forces in the Baltic states and Poland - enhanced Forward Presence (eFP). Within the discussion of the deployment, issue of the willingness to defend other Allies became relevant. Overall, it highlighted the challenges and lack of unity among Allies, as there are, for instance, still several Allies that are not present in any of the eFP battlegroups. It illustrates the perception of both political leaders and societies of various Allies that differ from one Ally to another.

This doesn't imply that Article 5 has been challenged. It remains the cornerstone of the Alliance deterrence and defence posture. In addition, NATO as a whole continues to be supported by the vast majority. Although tensions and issues exist among Allies, NATO's overall support and position is rock solid. However, when it comes to the practical steps, opinions of NATO and issues related to the Alliance vary widely across the countries. The sentiment of the society highlights the challenges of the overall willingness to step on the soil of an Ally from the very outset of the conflict or crisis. According to the survey made by Pew Research Center, "when asked if their country should defend a fellow NATO Ally against a potential attack from Russia, a median of 50\% across 16 NATO member states say their country should not defend an Ally, compared with 38\% who say their country should defend an Ally against a Russian attack"10. Half of the Allies' societies are against involvement in the conflict with Russia. This type of research only stimulates Russia's appetite to test the Alliance's unity and solidarity.

According to other survey made by the Institute of Land Warfare, significant negative indicators of political will do exist because of following reasons:

1. "NATO lacks sufficient key leaders who support the use of force to defend the Baltics. 
2. NATO displays evidence of diverging alliance missions, threats, interests, perceptions of Russia and domestic interests, all of which diminish common understanding of the threat.

3. NATO retains significant strength in the third component - a potentially-effective solution - due to latent military and economic power". ${ }^{11}$

The (un)willingness to protect Allies poses significant challenges in the context of collective defence. First of all, it affects the speed of decisionmaking. Aware that there is no consensus among the Allies, Russia will be able to exploit the lack of political will. By pursuing covert hybrid warfare, Russia may thus deter most of the Allies from engaging in the first phase of a conflict or crisis. Second, it may provide an incentive to Russia to implement a large-scale Anti Access / Area Denial (A2/AD) scenario. A large-scale and unexpected conventional attack could lead to the blockade of the Baltic states from the rest of the Alliance. In this case, the reinforcement of Allied forces will be crucial. The involvement of the Allies will be based on the willingness (support) of societies to protect the Baltic states, which have emerged during peacetime. Finally, the public's willingness to defend its Allies is particularly important in the context of new threats: cyber, strategic communications (disinformation), energy, etc. In order to meet the challenges posed by Russia (as well as China), the Alliance's common resilience and the Allies' willingness to improve each other is of utmost importance.

\section{Conclusions}

Strengthening deterrence and resilience is a permanent task. The Baltic region borders with an actor who exploits the opponent's weaknesses in its own interests. To deter such an adversary, the Alliance must continue to strengthen its capabilities, ensure an enhanced and integrated Allied force presence, and send signals that any form of aggression will provoke a broad and rapid collective response. The credibility of the messaging will be determined by society's desire to protect more than just its own country. The willingness to protect the Alliance is, therefore, a cornerstone of the deterrence and defence posture. 
From NATO's perspective, it is premature to predict that resilience in near or mid-term future will become, first and foremost, NATO's responsibility. Member States are expected strengthen their resilience internal and external shocks, thus, overall enhancing the Alliance's ability to adapt to new challenges. In this context, Article 3 of the North Atlantic Treaty is a complementary element to Article 5. By strengthening national resilience, NATO's collective defence is enhanced. If each member state individually and the Alliance as a whole is resilient to external attacks, this makes the Alliance stronger as a whole. In this context, it is important to identify the innovative areas and niche skills that each member state can contribute to a common NATO capability pot. It must be rather a complementary than competitive process. In this regard, NATO as unifying framework will be crucial to set the agenda and specific requirements when it comes to ensuring resilient society.

However, in recent years, differences among Allies in their threat perception as well as their willingness to defend other Allies have intensified. The ability to adapt to uncertain and ever-changing international security environment has been a precondition for NATO's success and development, and so will be the issue of resilience and willingness to engage. Since the founding of NATO in 1949, the Alliance has experienced several internal and external shocks that have eventually affected NATO's future existence. NATO has been able to adapt and find solutions to the challenges it faces. Russia's annexation of Crimea in 2014 was a wake-up call that highlighted gaps and weaknesses in the Alliance's perception, approach, and action. It also illustrated the importance of willingness, readiness, and ability of the society to take part in defence against any form of the attack. Without increased willingness to defend whole Alliance the adaptation process of the deterrence and defence posture is useless. Allied leaders and the Alliance as a whole need to find ways to raise awareness of the society that could stimulate the overall willingness to engage, if that is necessary. Otherwise, it creates an additional appetite for the adversary to test the unity and solidarity of the Alliance. 


\section{ENDNOTES}

1 NATO, Wales Summit Declaration, October 7, 2021, https://www.nato.int/cps/en/natohq/official_texts_112964.htm.

2 NATO, Warsaw Summit Communiqué, July 9, 2016, https://www.nato.int/cps/en/natohq/official_ texts_133169.htm.

3 NATO, Commitment to enhance resilience, July 8, 2016, https://www.nato.int/cps/en/natohq/official_texts_133180.htm.

4 NATO, Brussels Summit Communiqué, June 14, 2016, https://www.nato.int/cps/en/natohq/ news_185000.htm.

5 Ministry of Defence of the United Kingdom, Joint Doctrine Note 1/19 Deterrence: the Defence Contribution, https://assets.publishing.service.gov.uk/government/uploads/system/uploads/ attachment_data/file/860499/20190204-doctrine_uk_deterrence_jdn_1_19.pdf, 23.

6 Lawrence Freedman, The Future of War: A History. New York: PublicAffairs (2017), 67.

7 NATO, Strengthened Resilience Commitment. Jun 15. 2021. https://www.nato.int/cps/en/natohq/ official_texts_185340.htm.

8 NATO, Remarks by NATO Secretary General Jens Stoltenberg on launching \#NATO 2030 - Strengthening the Alliance in an increasingly competitive world, June 8, 2020, https://www.nato.int/cps/ en/natohq/opinions_176197.htm.

9 NATO, Remarks by NATO Secretary General Jens Stoltenberg on launching \#NATO 2030 - Strengthening the Alliance in an increasingly competitive world, June 8, 2020, https://www.nato.int/cps/ en/natohq/opinions_176197.htm.

${ }^{10}$ Pew Research Center, NATO Seen Favorably Across Member States, February 9, 2020, https:// www.pewresearch.org/global/2020/02/09/nato-seen-favorably-across-member-states/.

${ }^{11}$ Zachary Morris, The North Atlantic Treaty Organization: Dubious Political Will to Defend Baltic Allies, The Institute of Land Warfare, https://www.ausa.org/sites/default/files/publications/ LWP-120-The-North-Atlantic-Treaty-Organization-Dubious-Political-Will-To-Defend-Baltic-Allies.pdf, 20-21. 